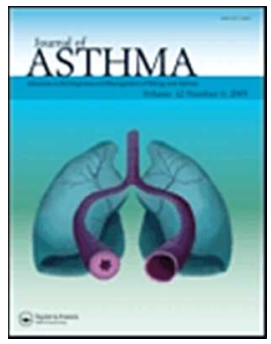

\title{
Peripheral killer cells do not differentiate between asthma patients with or without fixed airway obstruction
}

\begin{tabular}{|r|l|}
\hline Journal: & Journal of Asthma \\
\hline Manuscript ID & LJAS-2016-0154.R1 \\
\hline Manuscript Type: & Original \\
\hline Keywords: & $\begin{array}{l}\text { Biomarkers, Immunopathogenesis, Mechanisms, Pathophysiology, } \\
\text { Phenotypes }\end{array}$ \\
\hline \multicolumn{2}{|l}{} \\
\hline
\end{tabular}




\title{
Peripheral killer cells do not differentiate between asthma
}

\section{patients with or without fixed airway obstruction}

\author{
Abstract \\ Objective: The three main types of killer cells - CD8 ${ }^{+} \mathrm{T}$ cells, NK cells and NKT \\ cells - have been linked to asthma and chronic obstructive pulmonary disease \\ (COPD). However, their role in a small subset of asthma patients displaying fixed \\ airway obstruction (FAO), similar to that seen in COPD, has not been explored. \\ The objective of the present study was to investigate killer cell numbers, \\ phenotype and function in peripheral blood from asthma patients with FAO, \\ asthma patients without FAO, and healthy individuals. Methods: Peripheral \\ $\mathrm{CD}^{+}{ }^{+} \mathrm{T}$ cells $\left(\mathrm{CD}^{+}{ }^{+} \mathrm{CD}^{+}{ }^{+} \mathrm{CD} 56^{-}\right)$, NK cells (CD56 $\left.{ }^{+} \mathrm{CD} 3^{-}\right)$and NKT-like cells \\ $\left(\mathrm{CD}^{2} 6^{+} \mathrm{CD}^{+}\right)$of 14 asthma patients with FAO (post-bronchodilator FEV/FVC \\ $<0.7$, despite clinician-optimised treatment), 7 asthma patients without FAO \\ (post-bronchodilator FEV/FVC $\geq 0.7$ ), and 9 healthy individuals were studied. \\ Results: No significant differences were seen between the number, receptor \\ expression, MAPK signalling molecule expression, cytotoxic mediator expression, \\ and functional cytotoxicity of peripheral killer cells from asthma patients with \\ FAO, asthma patients without FAO and healthy individuals. Conclusions: \\ Peripheral killer cell numbers or functions do not differentiate between asthma \\ patients with or without fixed airway obstruction.

\section{Keywords} \\ CD8+ T cells; fixed airflow obstruction; natural killer cells; natural killer T cells; \\ protein lysate microarray; asthma.
}




\section{Introduction}

Asthma is a chronic inflammatory disease of the airways, with over 200 million individuals affected worldwide [1]. It is characterised by airway hyperresponsiveness and remodelling resulting in coughing, breathlessness and chest tightness. Asthma encompasses a variety of clinical phenotypes ranging from what was classically defined as extrinsic allergic (IgE-mediated) asthma to intrinsic non-allergic asthma [2]. Recent genomic, transcriptomic and proteomic investigations of asthma, in combination with clinico-pathological parameters, have led to the realisation that clinically-diagnosed asthma encompasses a diverse and complex set of conditions referred to as 'endotypes' [3-5]. These range from classical allergic asthma (Th2-driven, IgE-mediated , eosinophilic), through neutrophilic asthma associated with the activation of innate immunity, to asthma involving little inflammation, but extensive airway remodelling [3-5]. It has also become apparent that the traditional distinction between asthma and chronic obstructive pulmonary disease (COPD) is not always applicable, with some patients having features of both of these conditions [6-8].

The majority of people with asthma display airflow obstruction that is episodic and returns to normal either spontaneously or following appropriate treatment. However, a minority of people with asthma display airflow obstruction that does not respond to treatment, i.e. can be described as 'fixed' ([9-22], reviewed in [23]). This fixed airflow obstruction (FA0) is a feature more commonly associated with COPD [24]. It is not known why some asthma patients develop FAO. It may be a consequence of more severe asthma, duration of asthma, or it may represent a separate disease entirely. 
In recent years, interest and investigations into the potential role of killer cells in asthma and COPD have steadily increased. CD8 T cells, NK cells and NKT cells are the three main killer cells types; their effector functions include cellular cytotoxicity and immunoregulation [25-36]. Killer cells are thought also to contribute to COPD [37-39]. We have previously shown that, in COPD, the numbers of peripheral blood NK and NK-T cells were reduced and that their cytotoxic function was defective compared to healthy smokers and neversmokers [40].

Far fewer studies have looked at the role that killer cells play in asthma with FAO. Immunohistochemistry has shown the degree of FAO to be significantly correlated to the number of CD8 T cells in bronchial biopsies [19]. In this study, we have investigated the number and function of peripheral human killer cells in asthma with or without FAO to see if these differ, and to determine whether asthma with FAO is more similar to COPD or asthma without FAO in this respect.

\section{Material and methods}

\section{Study population and procedures}

The Nottingham Local Research Ethics Committee approved the study protocol (REC reference 10/H0405/2) and informed written consent was taken prior to subjects enrolling on to the study. Thirty individuals were recruited into three participant groups: asthma with fixed airflow obstruction $(\mathrm{A}+\mathrm{FAO})$, asthma without FAO (A-FAO), and healthy controls (H). All asthma subjects had a clinical diagnosis. Asthma patients with FAO had a post-bronchodilator FEV/FVC <0.7, despite clinician-optimised treatment [41]; while asthma patients without FAO 
had a post-bronchodilator FEV/FVC $\geq 0.7$. The bronchodilator $(400 \mu \mathrm{g}$ salbutamol) was administered 20 minutes prior to spirometry. All participants were age-matched, had no co-morbidities, were ex or non-smokers with a pack history of $\leq 10 y e a r s$, and had no infections within the previous six weeks. The demographic and spirometric data of the 30 study participants used to investigate killer cell number, surface receptor expression and intracellular cytotoxic mediator expression are shown in Table 1a; details of the 20 participants whose MAPK signalling molecule expression were analysed are shown in Table 1b; while the details of the 18 participants whose NK cell cytotoxicity levels were measured are shown in Table 1c.

\section{Absolute cell counting}

To quantify killer cell numbers, fluorescently labelled antibodies specific for several killer cell markers, shown in Table 2, were added to $100 \mu \mathrm{l}$ whole peripheral blood at half the recommended concentration and left in the dark for 15 minutes. Optilyse C solution (Beckman Coulter, A11895) was used to lyse the red blood cells and was diluted with an equal volume of phosphate buffered saline (PBS, Sigma D8537) after 10 minutes. Finally, $100 \mu \mathrm{l}$ of flow-count fluorosphere beads (Beckman Coulter, 7547053) were added to each tube, before immediate analysis on a Beckman Coulter FC500 flow cytometer.

\section{Peripheral blood mononuclear cell (PBMC) and killer cell isolation}

To obtain PBMCs, peripheral whole blood was diluted to a ratio of 2:1 with RPMI-1640 media (Sigma, R8758), layered over histopaque (Sigma, H8889) and 
centrifugated at $800 \mathrm{~g}$ for 23 minutes. The resulting PBMC layer was harvested. CD8 T cells, NK cells and NKT-like cells were isolated from PBMCs via immunomagnetic separation using a CD56 multisort kit (Miltenyi Biotec, 130055-401) and CD3 and CD8 microbeads (Miltenyi Biotec, 130-050-101 and 130045-201, respectively) according to the supplied protocols. Briefly, PBMCs were incubated with CD56 microbeads, washed, and passed through an MS column situated within a MACS magnet. After microbead release, using the supplied reagent, and another wash, the $\mathrm{CD}^{2} 6^{+}$fraction was incubated with $\mathrm{CD} 3$ microbeads; while the CD56- fraction was incubated with CD8 microbeads. Both fractions were run through a fresh MS column, which yielded a CD56+CD3fraction (NK cells), a CD56+CD3+ fraction (NKT-like cells), and a CD56-CD8+ fraction (CD8 T cells). All reagents and incubation steps were used and performed at $4^{\circ} \mathrm{C}$. A portion of each fraction was removed, stained extracellularly and analysed by flow cytometry to ascertain purity. The median CD8 T cell purity was above $92 \%$, the median NK cell purity was above $97 \%$, and the median NKT cell purity was above $74 \%$.

\section{Flow cytometry}

Killer cell purity, surface receptor expression, and intracellular cytotoxic mediator expression were all analysed by flow cytometry. Briefly, cells were quick-fixed using a 3\% formaldehyde fix solution. Those stained extracellularly were washed in phosphate buffered albumin (PBA- PBS (Oxoid BR0014G) with 1\% BSA (Sigma A7284) and 0.1\% $\mathrm{NaN}_{3}$ (Sigma S8032)), incubated with fluorescently-conjugated antibodies (see Table 2) for 30 minutes in the dark, and washed again. Those stained intracellularly were washed with $0.04 \%$ PBA- 
saponin (Sigma, S4521) followed by PBA-saponin with 10\% FCS, before a twohour incubation and a final wash in PBA-saponin. All cells were stored in a $0.5 \%$ formaldehyde fix solution until analysis. Fluorescence-minus-one controls, containing all the antibodies bar one, were also included. Flow cytometry analysis was performed on a Beckman Coulter FC500 flow cytometer, with 50 000 events collected for each sample. Dead cells were excluded based on their forward (size) and side scatter (granularity).

\section{Reverse-phase protein microarray (RPPA) analysis}

An in-house cell lysate microarray system was used to quantify killer cell cytotoxic signalling molecule levels [42]. Briefly, samples were printed onto 16 pad nitrocellulose slides (Grace BioLabs) using a Microgrid II arraying robot (Digilab Inc., Marlborough, MA, USA). Slides were blocked, washed and probed with marker-specific rabbit antibodies (Cell Signaling Technology) and mouse anti-human $\beta$-actin control antibody (Sigma Aldrich, UK). Antibody binding was visualized by incubating with goat anti-mouse IR680 and goat anti-rabbit IR00 infrared secondary antibodies (Li-Cor BioSciences) diluted 1:5000 in 0.1\% TBSTween for 30 minutes in the dark. Having been washed, rinsed with ultrapure water, and dried; the slides were scanned at 700nm and $800 \mathrm{~nm}$ wavelengths on a Li-Cor Odyssey scanner (LI-COR Biosciences). Fluorescent signal for each feature (spot) was determined using Axon GenePix Pro software (Axon Instruments Inc.) Local background was subtracted and signals were normalized to $\beta$ actin levels using the R statistical language and the RPPAnalyser module. 


\section{Cytotoxicity assay}

NK cell cytotoxicity was quantified using a non-radioactive LDH release assay kit (Promega, G1780) and the K562 human myelogenous leukaemia cell line (ECACC). The cell line was cultured in a $37^{\circ} \mathrm{C}$ incubator using RPMI-1640 media (Sigma, R8758) with 10\% FCS (HyClone, CH30160.03).

Kit instructions were followed. Briefly, the K562 and NK cells were washed twice in RPMI-1640 media without phenol red (Invitrogen, 11835063), and placed at an effector:target ratio of 10:1 in a U-bottomed 96 well tissue culture plate (Nunc, 163320), in quadruplicate. Following a four-hour incubation at $37^{\circ} \mathrm{C}$ and subsequent centrifugation, $50 \mu \mathrm{l}$ of supernatant from each well was transferred to a flat-bottomed 96 well tissue culture plate (Nunc, 167008) and mixed with an equal volume of substrate mix (supplied with kit) to quantify LDH levels. After 30 minutes in the dark, the reaction was stopped and the absorbance read at 492nm on a BMG Labtech FLUOstar Optima spectrophotometer. Cytotoxicity was calculated as a percentage using the following equation:

Cytotoxicity $(\%)=[($ effector/target mix- spontaneous effector LDH release- spontaneous target LDH release)/(maximum target LDH releasespontaneous target LDH release)] x 100

\section{Statistical analysis}

Flow cytometry data were analysed using Weasel v2.7 software. The spot intensity of the microarray samples was measured using Genepix software, before RPPanalyzer software corrected for background, normalised to the actin signal of the same spot, and amplified the intensity of each spot. Subsequent 
analysis of all data was performed with Prism 4.0 software. For visibly skewed data, the values were first log transformed, before the normality of the data was tested using the D'Agostino and Pearson omnibus normality test. Differences between parametric data were explored using the one-way ANOVA test, while differences between non-parametric data were explored using the Kruskal Wallis test. Any pairs of groups holding statistical significance $(\mathrm{p}<0.05)$ following the ANOVA test were identified using the Tukey's multiple comparison post-hoc test.

\section{Results}

\section{Peripheral killer cell numbers}

Peripheral CD8 T cell (CD8 $\left.{ }^{+} \mathrm{CD}^{+} \mathrm{CD}^{-} 6^{-}\right)$, NK cell $\left(\mathrm{CD} 56^{+} \mathrm{CD} 3^{-}\right)$and NKT-like cell $\left(\mathrm{CD}^{2} 6^{+} \mathrm{CD}^{+}\right)$numbers were quantified using absolute cell counting (Fig. 1). There were no statistically significant differences between the numbers or proportions of each killer cell type across the three participant groups (asthma patients with or without FAO and healthy controls).

Subsets of the killer cell types were also quantified using this method (data not shown). These subsets included: naïve (CD45RA+CCR7+), central memory (CM, CD45RA-CCR7+'), effector memory (EM, CD45RA-CCR7-) and effector T (Eff T, CD45RA+CCR7-) CD8 T cells [43]; CD56 ${ }^{\mathrm{dim}}\left(\mathrm{CD}^{+} 6^{+} / \mathrm{CD}^{-} 6^{+}\right)$and CD56 ${ }^{\text {bright }}\left(\mathrm{CD}^{2} 6^{++} / \mathrm{CD}^{-} 6^{-}\right)$NK cells [44]; and CD4-CD8-, CD4+CD8-, CD4-CD8+ and $\mathrm{CD}^{+}{ }^{+} \mathrm{CD} 8+$ NKT-like cells [45]. Again, no significant differences were seen between the three participant groups for any of these subsets. 


\section{Peripheral killer cell NKG2D and KIR3DL1 receptor expression}

Peripheral killer cell ex vivo expression of the activatory NKG2D and inhibitory KIR3DL1 receptors was quantified using flow cytometry (Fig. 2). No statistically significant differences were present between the participant groups for NKG2D or KIR3DL1 expression for any of the killer cell types.

The killer cell expression of a further four receptors (activatory KLRC2 and KIR2DS4, and inhibitory KLRD1 and KIR2DL2) was analysed by RPMA (data not shown). There were no significant differences in the expression of these four receptors between the participant groups for any of the killer cell types.

\section{Peripheral killer cell cytotoxic signalling molecule expression}

Peripheral CD8 T cells, NK cells and NKT-like cells were isolated (to purities of $>92 \%,>97 \%$ and $>74 \%$, respectively), before their expression of total and phosphorylated ERK1/2, total and phosphorylated SAPK/JNK and total p38 MAPK was measured by RPMA and compared between asthma patients with and without FAO and healthy individuals (Fig. 3). There were no significant differences in the expression of the aforementioned signalling molecules in the three isolated killer cell types.

\section{Peripheral killer cell cytotoxic function}

The peripheral killer cell ex vivo intracellular expression of the cytotoxic mediators perforin and granzyme B was analysed by flow cytometry and compared across the three participant groups (Fig. 4). There were no significant differences in the expression of either of these cytotoxic mediators between the participant groups for any of the three killer cell types. While most CD8 T cells 
expressed neither perforin nor granzyme B (Fig. 4a); the majority of NK cells expressed both cytotoxic mediators (Fig. 4f).

Peripheral NK cells were isolated to a purity of over 97\%, before their cytotoxicity levels were quantified using the K562 cell line and a non-radioactive LDH release assay (Fig. 5). There were no statistically significant differences in NK cell cytotoxicity levels between the three participant groups.

\section{Discussion}

The work presented here shows that the number and function of killer cells in a small subset of asthma patients who display FAO are similar to those in asthma patients without FAO and in healthy controls. This is distinctly different from our previous findings concerning peripheral killer cells in COPD [40, 46].

CD8 T cell subsets can have opposing effects in asthma: Tc1 CD8 T cells protect against asthma, by mediating IL-12 and IL-18 Th1 cytokine production from dendritic cells [26]; whereas Tc2 CD8 T cells are thought to contribute to the inflammatory profile seen in asthma patients [26]. NK cell subsets have also been shown to have opposing effects in asthma [27, 31, 35]. NKT cells have been implicated in asthma $[25,30]$ as they produce Th2 cytokines, such as IL-4, IL-5 and IL-13, which recruit eosinophils and promote B cell class switching [32-34]. However, NKT cells are also capable of cytotoxicity and producing Th1 cytokines; thereby inhibiting the actions of the Th2 cytokine-producing NKT cells involved in the pathogenesis of asthma $[28,29,36]$.

No significant differences were observed in peripheral NK or NKT-like cell numbers or proportions between the three participant groups in the present study (healthy controls, asthma patients without FAO and asthma patients with 
FAO), whereas COPD patients were found to have significantly lower proportions of peripheral NK and NK-T cells than healthy controls (both never-smokers and smokers) [40]. A point of caution in drawing firm conclusions from the present results is the relatively small numbers of subjects in the healthy control, asthma without FAO and asthma with FAO groups, which limits the power of the study; although, having said that, similar numbers of subjects were used in our previous study that did show significant differences between peripheral killer cells in COPD patients and healthy controls [40]. However, it is clear that any differences in the number or proportions of killer cells between the healthy control, asthma without FAO and asthma with FAO groups are marginal, since power calculations showed that the numbers of subjects in each group required for $80 \%$ power would need to be 121 for the proportion of CD8 T cells, 468 for NK cell proportions and 84 for NKT-like cell proportions. Furthermore, modelling of the data in figure 1 with ten times more data points (but with the same distribution of data) still did not predict there to be any significant differences in killer cell numbers/proportions between the asthma patients without or with FAO.

In addition, no significant differences were observed in the proportion of peripheral CD8 T cells or NKT-like cells expressing both perforin and granzyme $B$ between the three participant groups in the present study, whereas these proportions were found to be significantly decreased in COPD patients compared to healthy controls (both never-smokers and smokers) [40]. Again, despite the relatively small size of the healthy control, asthma without FAO and asthma with FAO groups in the present study, the lack of significant differences in the proportions of perforin ${ }^{+} /$granzyme- $\mathrm{B}^{+}$cells is supported by power calculations 
indicating that the number of subjects required for $80 \%$ power would be 2113

for CD8+ T cells, 201 for NK cells and 1875 for NKT-like cells; and that modelling

of the data with ten time more data points and the same distributions still

predicts there to be no significant differences.

Furthermore, no significant differences were observed in the cytotoxic activity of peripheral NK cells between the three participant groups in the present study, whereas these cells were found to have significantly lower cytotoxic activity in COPD patients than in healthy controls (both never-smokers and smokers) [40]. However, the relatively small group sizes require there to be cautious interpretation of the data.

Overall, with respect to these observations concerning peripheral killer cells, asthma with FAO is unlike COPD and is more akin to asthma without FAO. This is despite FAO being a feature more usually associated with COPD than with asthma. In otherwords, asthma with FAO displays a combination of features that distinguish it both from asthma without FAO and from COPD.

Expression of KIR3DL1 (also known as CD158e1) by peripheral killer cells does not distinguish asthma with or without FAO from COPD, since this is unchanged in all three of these disease states compared to healthy (neversmoker) controls [46]; indeed, smoking per se (rather than COPD) leads to reduced KIR3DL1/CD158e1 expression by peripheral killer cells [46]. NKG2D expression by peripheral killer cells is also normal in asthma with or without FAO and in COPD [46].

With regards to the signalling molecule expression results, no significant differences were observed between healthy controls and asthma patients with or without FAO. It is, however, interesting to note the similarities between the NK 
cell profiles of phosphorylated (activated) ERK1/2 and cellular cytotoxicity. In both, the levels in healthy individuals and asthma patients with FAO were similar, while those of asthma patients without FAO were slightly elevated (although not significantly - possibly due to insufficient numbers). ERK1/2 is necessary for NK cell cytotoxicity $[47,48]$ and has been shown to be elevated in asthma patients without FAO compared to healthy individuals [49]. This is the first time it has been specifically investigated in asthma patients with FAO.

A key difference in the pathology of COPD compared to asthma with FAO is the association of chronic bronchitis and/or emphysema with COPD. Our findings in relation to killer cells in COPD and, reported here, for asthma with or without FAO, may help to explain these differences. In particular, the reduced numbers and effector function of peripheral killer cells in COPD [40] was found to correlate inversely with increased numbers, activation state and effector function of lung-associated killer cells in the induced sputum of COPD patients $[37,46]$. Thus, the recruitment to pulmonary tissues, and activation, of killer cells in COPD may contribute to the inflammation and tissue destruction leading to the development of chronic bronchitis and/or emphysema. Conversely, the relatively normal numbers and function of peripheral killer cells in asthma with or without FAO may be indicative of their lack of recruitment to the lungs and the absence of chronic bronchitis and emphysema. It is thus apparent that a main limitation of the present study is that only peripheral killer cells were investigated. Although inflammatory cells are recruited from the periphery to the lung, both the origin of systemic inflammation and its relationship to the pulmonary inflammation of asthma remain unclear [50]. Therefore, although these results are clinically relevant, further study using material derived from 
the lung would be required to show the recruitment, and the potential role, of killer cells in the pathogenesis of asthma with FAO.

Although the present study does not elucidate the basis for the different features of asthma without or with FAO, it does imply that this is not a consequence of differences in killer cell numbers or activity. Further studies are therefore required to understand these differences.

Regarding our definition of FAO (post-bronchodilator FEV/FVC $<0.7$, despite clinician-optimised treatment [41]), we believe the length of disease duration of the asthma patients with FAO (a median of 45 years) allowed us to classify this airflow obstruction as fixed; although repeated spirometry measurements would have been desirable. Furthermore, an oral corticosteroid trial could be considered necessary to fully confirm fixed airflow obstruction but, as all patients were on inhaled steroids, this was not deemed ethically acceptable.

In summary, the three main types of killer cells - CD8 T cells, NK cells and NKT-like cells - are similar in peripheral blood in asthma patients and healthy controls. The observation that peripheral killer cells are similar in asthma with FAO and in asthma without FAO indicates that peripheral killer cell phenotype and function is not linked to the differences in lung function associated with these clinically distinct endotypes of asthma. Furthermore, these findings are different from our previous observations concerning peripheral killer cells in COPD [40], indicating that asthma with FAO and COPD are distinct phenotypes. 


\section{References}

1. Ferkol T, Schraufnagel D: The global burden of respiratory disease. Ann Am Thorac Soc 2014, 11:404-406.

2. Romanet-Manent S, Charpin D, Magnan A, Lanteaume A, Vervloet D, Group EC: Allergic vs nonallergic asthma: what makes the difference? Allergy 2002, 57:607-613.

3. Agache I, Akdis C, Jutel M, Virchow JC: Untangling asthma phenotypes and endotypes. Allergy 2012, 67:835-846.

4. Corren J: Asthma phenotypes and endotypes: an evolving paradigm for classification. Discov Med 2013, 15:243-249.

5. George BJ, Reif DM, Gallagher JE, Williams-DeVane CR, Heidenfelder BL, Hudgens EE, Jones W, Neas L, Hubal EA, Edwards SW: Data-driven asthma endotypes defined from blood biomarker and gene expression data. PLoS One 2015, 10:e0117445.

6. Bell MC, Busse WW: Is It Asthma or Is It COPD: The Overlap Syndrome. J Allergy Clin Immunol Pract 2015, 3:641-642; quiz 643.

7. Tamada T, Sugiura H, Takahashi T, Matsunaga K, Kimura K, Katsumata U, Takekoshi D, Kikuchi T, Ohta K, Ichinose M: Biomarker-based detection of asthma-COPD overlap syndrome in COPD populations. Int J Chron Obstruct Pulmon Dis 2015, 10:2169-2176.

8. Vanfleteren LE, Kocks JW, Stone IS, Breyer-Kohansal R, Greulich T, Lacedonia D, Buhl R, Fabbri LM, Pavord ID, Barnes N, et al: Moving from the Oslerian paradigm to the post-genomic era: are asthma and COPD outdated terms? Thorax 2014, 69:72-79.

9. Boulet LP, Turcotte H, Turcot 0 , Chakir J: Airway inflammation in asthma with incomplete reversibility of airflow obstruction. Respir Med 2003, 97:739-744.

10. Bumbacea D, Campbell D, Nguyen L, Carr D, Barnes PJ, Robinson D, Chung KF: Parameters associated with persistent airflow obstruction in chronic severe asthma. Eur Respir J 2004, 24:122-128.

11. Di Lorenzo G, Mansueto P, Ditta V, Esposito-Pellitteri M, Lo Bianco C, LetoBarone MS, D'Alcamo A, Farina C, Di Fede G, Gervasi F, et al: Similarity and differences in elderly patients with fixed airflow obstruction by asthma and by chronic obstructive pulmonary disease. Respir Med 2008, 102:232-238.

12. Fabbri LM, Romagnoli M, Corbetta L, Casoni G, Busljetic K, Turato G, Ligabue G, Ciaccia A, Saetta M, Papi A: Differences in airway inflammation in patients with fixed airflow obstruction due to asthma or chronic obstructive pulmonary disease. Am J Respir Crit Care Med 2003, 167:418424.

13. Guerra S, Martinez FD: Epidemiology of the origins of airflow limitation in asthma. Proc Am Thorac Soc 2009, 6:707-711.

14. Guerra S, Sherrill DL, Kurzius-Spencer M, Venker C, Halonen M, Quan SF, Martinez FD: The course of persistent airflow limitation in subjects with and without asthma. Respir Med 2008, 102:1473-1482.

15. Lee JH, Haselkorn T, Borish L, Rasouliyan L, Chipps BE, Wenzel SE: Risk factors associated with persistent airflow limitation in severe or difficult- 
to-treat asthma: insights from the TENOR study. Chest 2007, 132:18821889.

16. Selivanova PA, Kulikov ES, Kozina OV, Gereng EA, Freidin MB, Ogorodova LM: Morphological and molecular characteristics of "difficult" asthma. J Asthma 2010, 47:269-275.

17. Shaw DE, Berry MA, Hargadon B, McKenna S, Shelley MJ, Green RH, Brightling CE, Wardlaw AJ, Pavord ID: Association between neutrophilic airway inflammation and airflow limitation in adults with asthma. Chest 2007, 132:1871-1875.

18. Tsoumakidou M, Tzanakis N, Kyriakou D, Chrysofakis G, Siafakas NM: Inflammatory cell profiles and T-lymphocyte subsets in chronic obstructive pulmonary disease and severe persistent asthma. Clin Exp Allergy 2004, 34:234-240.

19. van Rensen EL, Sont JK, Evertse CE, Willems LN, Mauad T, Hiemstra PS, Sterk PJ: Bronchial CD8 cell infiltrate and lung function decline in asthma. Am J Respir Crit Care Med 2005, 172:837-841.

20. Vonk JM, Jongepier H, Panhuysen CI, Schouten JP, Bleecker ER, Postma DS: Risk factors associated with the presence of irreversible airflow limitation and reduced transfer coefficient in patients with asthma after 26 years of follow up. Thorax 2003, 58:322-327.

21. Fattahi F, Vonk JM, Bulkmans N, Fleischeuer R, Gouw A, Grunberg K, Mauad T, Popper H, Felipe-Silva A, Vrugt B, et al: Old dilemma: asthma with irreversible airway obstruction or COPD. Virchows Arch 2015, 467:583-593.

22. Zhang L, He L, Gong J, Liu C: Risk Factors Associated with Irreversible Airway Obstruction in Asthma: A Systematic Review and Meta-Analysis. Biomed Res Int 2016, 2016:9868704.

23. Tubby C, Harrison T, Todd I, Fairclough L: Immunological basis of reversible and fixed airways disease. Clinical science 2011, 121:285-296.

24. Celli BR, MacNee W: Standards for the diagnosis and treatment of patients with COPD: a summary of the ATS/ERS position paper. Eur Respir J 2004, 23:932-946.

25. Akbari O, Faul JL, Hoyte EG, Berry GJ, Wahlstrom J, Kronenberg M, DeKruyff RH, Umetsu DT: CD4+ invariant T-cell-receptor+ natural killer T cells in bronchial asthma. N Engl J Med 2006, 354:1117-1129.

26. Betts RJ, Kemeny DM: CD8+ T cells in asthma: friend or foe? Pharmacol Ther 2009, 121:123-131.

27. Culley FJ: Natural killer cells in infection and inflammation of the lung. Immunology 2009, 128:151-163.

28. Godfrey DI, Kronenberg M: Going both ways: immune regulation via CD1d-dependent NKT cells. J Clin Invest 2004, 114:1379-1388.

29. Kuylenstierna C, Bjorkstrom NK, Andersson SK, Sahlstrom P, Bosnjak L, Paquin-Proulx D, Malmberg KJ, Ljunggren HG, Moll M, Sandberg JK: NKG2D performs two functions in invariant NKT cells: direct TCRindependent activation of NK-like cytolysis and co-stimulation of activation by CD1d. Eur J Immunol 2011, 41:1913-1923.

30. Lombardi V, Stock P, Singh AK, Kerzerho J, Yang W, Sullivan BA, Li X, Shiratsuchi T, Hnatiuk NE, Howell AR, et al: A CD1d-dependent antagonist inhibits the activation of invariant NKT cells and prevents development of 
allergen-induced airway hyperreactivity. J Immunol 2010, 184:21072115.

31. Ple C, Barrier M, Amniai L, Marquillies P, Bertout J, Tsicopoulos A, Walzer

T, Lassalle P, Duez C: Natural killer cells accumulate in lung-draining lymph nodes and regulate airway eosinophilia in a murine model of asthma. Scandinavian Journal of Immunology 2010, 72:118-127.

32. Sakuishi K, Oki S, Araki M, Porcelli SA, Miyake S, Yamamura T: Invariant NKT cells biased for IL-5 production act as crucial regulators of inflammation. J Immunol 2007, 179:3452-3462.

33. Stock P, Lombardi V, Kohlrautz V, Akbari O: Induction of airway hyperreactivity by IL-25 is dependent on a subset of invariant NKT cells expressing IL-17RB. J Immunol 2009, 182:5116-5122.

34. Terashima A, Watarai H, Inoue S, Sekine E, Nakagawa R, Hase K, Iwamura C, Nakajima H, Nakayama T, Taniguchi M: A novel subset of mouse NKT cells bearing the IL-17 receptor B responds to IL-25 and contributes to airway hyperreactivity. J Exp Med 2008, 205:2727-2733.

35. Wei H, Zhang J, Xiao W, Feng J, Sun R, Tian Z: Involvement of human natural killer cells in asthma pathogenesis: natural killer 2 cells in type 2 cytokine predominance. J Allergy Clin Immunol 2005, 115:841-847.

36. Wingender G, Krebs P, Beutler B, Kronenberg M: Antigen-specific cytotoxicity by invariant NKT cells in vivo is CD95/CD178-dependent and is correlated with antigenic potency. J Immunol 2010, 185:2721-2729.

37. Urbanowicz RA, Lamb JR, Todd I, Corne JM, Fairclough LC: Enhanced effector function of cytotoxic cells in the induced sputum of COPD patients. Respir Res 2010, 11:76-84.

38. Kim EY, Battaile JT, Patel AC, You Y, Agapov E, Grayson MH, Benoit LA, Byers DE, Alevy Y, Tucker J, et al: Persistent activation of an innate immune response translates respiratory viral infection into chronic lung disease. Nat Med 2008, 14:633-640.

39. Fairclough L, Urbanowicz RA, Corne J, Lamb JR: Killer cells in chronic obstructive pulmonary disease. Clin Sci (Lond) 2008, 114:533-541.

40. Urbanowicz RA, Lamb JR, Todd I, Corne JM, Fairclough LC: Altered effector function of peripheral cytotoxic cells in COPD. Respir Res 2009, 10:53-65.

41. GOLD: Global strategy for the diagnosis, management and prevention of chronic obstructive pulmonary disease. . 2013.

42. Negm OH, Mannsperger HA, McDermott EM, Drewe E, Powell RJ, Todd I, Fairclough LC, Tighe PJ: A pro-inflammatory signalome is constitutively activated by C33Y mutant TNF receptor 1 in TNF receptor-associated periodic syndrome (TRAPS). Eur J Immunol 2014, 44:2096-2110.

43. Champagne P, Ogg GS, King AS, Knabenhans C, Ellefsen K, Nobile M, Appay V, Rizzardi GP, Fleury S, Lipp M, et al: Skewed maturation of memory HIVspecific CD8 T lymphocytes. Nature 2001, 410:106-111.

44. Lanier LL, Testi R, Bindl J, Phillips JH: Identity of Leu-19 (CD56) leukocyte differentiation antigen and neural cell adhesion molecule. J Exp Med 1989, 169:2233-2238.

45. Godfrey DI, Stankovic S, Baxter AG: Raising the NKT cell family. Nat Immunol 2010, 11:197-206.

46. Wang J, Urbanowicz RA, Tighe PJ, Todd I, Corne JM, Fairclough LC: Differential activation of killer cells in the circulation and the lung: a study 
of current smoking status and chronic obstructive pulmonary disease (COPD). PLoS One 2013, 8:e58556.

47. Li C, Ge B, Nicotra M, Stern JN, Kopcow HD, Chen X, Strominger JL: JNK MAP kinase activation is required for MTOC and granule polarization in NKG2D-mediated NK cell cytotoxicity. Proc Natl Acad Sci U S A 2008, 105:3017-3022.

48. Chen X, Trivedi PP, Ge B, Krzewski K, Strominger JL: Many NK cell receptors activate ERK2 and JNK1 to trigger microtubule organizing center and granule polarization and cytotoxicity. Proc Natl Acad Sci U S A 2007, 104:6329-6334.

49. Liu W, Liang Q, Balzar S, Wenzel S, Gorska M, Alam R: Cell-specific activation profile of extracellular signal-regulated kinase $1 / 2$, Jun $\mathrm{N}$ terminal kinase, and p38 mitogen-activated protein kinases in asthmatic airways. J Allergy Clin Immunol 2008, 121:893-902 e892.

50. Wouters EF, Reynaert NL, Dentener MA, Vernooy JH: Systemic and local inflammation in asthma and chronic obstructive pulmonary disease: is there a connection? Proc Am Thorac Soc 2009, 6:638-647.

51. GINA: Global strategy for asthma management and prevention. 2012; http://www.ginasthma.org/documents/5/documents_variants/37. 


\section{Figure legends}

Figure 1. Peripheral killer cell numbers in asthma patients with and without FAO (A+FAO, A-FAO) and healthy individuals $(\mathrm{H})$. Whole blood was mixed with flow-count fluorosphere beads, incubated with fluorescently-conjugated antibodies and analysed by flow cytometry. Lymphocytes (L) and flow-count fluorosphere beads (B) were identified based on forward and side scatter (a). CD8 T cells (CD8+CD3+CD56-, b-e), NK cells (CD56+CD3-, f-i) and NKT-like cells $(\mathrm{CD} 56+\mathrm{CD} 3+, \mathbf{j}-\mathbf{l})$ were identified from the lymphocyte population (representative plots shown) and displayed as cells per $\mu \mathrm{l}(\mathbf{d}, \mathbf{h}, \mathbf{k})$ and as a proportion of the total killer cell number $(\mathbf{e}, \mathbf{i}, \mathbf{l})$. There were no statistically significant differences in killer cell number, or the proportion of the killer cell total this value represented, between the three participant groups for any of the three killer cell types. (h) and (k) log transformed. All data analysed by ANOVA.

Figure 2. NKG2D and KIR3DL1 receptor expression in killer cells from asthma patients with and without FAO $(\mathrm{A}+\mathrm{FAO}, \mathrm{A}-\mathrm{FAO})$ and healthy individuals $(\mathrm{H})$. Separated PBMC were stained with fluorescently-conjugated antibodies and analysed by flow cytometry. CD8 T cells (a-c), NK cells (d-f) and NKT-like cells (g-i) were identified (representative plots shown), and the NKG2D and KIR3DL1 expression of each was displayed as mean fluorescence intensity (MFI). There were no statistically significant differences in NKG2D or KIR3DL1 expression between the three participant groups for any of the killer cell types. (i) Log transformed. All data analysed by ANOVA. 
Figure 3. MAPK signalling molecule expression in killer cells from asthma patients with and without FAO $(\mathrm{A}+\mathrm{FAO}, \mathrm{A}-\mathrm{FAO})$ and healthy individuals $(\mathrm{H})$. Levels of total (T) and phosphorylated (P) ERK1/2, SAPK/JNK and p38 MAPK were measured in isolated CD8 T cells (a-e), NK cells (f-j) and NKT-like cells (ko), by reverse phase protein lysate microarray (RPMA). Background values were subtracted from the signal intensities, before normalisation to actin expression. There were no statistically significant differences in the expression of any of the signalling molecules between the three participant groups for any of the three killer cell types. Values are expressed in relative fluorescent units (RFU). (b), (e), (k), (l) and (o) Log transformed. All data analysed by ANOVA, except (j)analysed by Kruskal Wallis.

Figure 4. Perforin and granzyme B expression in killer cells from asthma patients with and without FAO $(\mathrm{A}+\mathrm{FAO}, \mathrm{A}-\mathrm{FAO})$ and healthy individuals $(\mathrm{H})$. PBMC were isolated and stained with fluorescently-conjugated antibodies before analysis by flow cytometry. CD8 T cells (a-d), NK cells (e-h) and NKT-like cells (il) were identified and the perforin and/or granzyme B expression of each was quantified. There were no statistically significant differences in the expression of either of the two cytotoxic mediators between the three participant groups for any of the killer cell types. (c), (d), (h), (k) and (l) Log transformed. All data analysed by ANOVA, except (j)- analysed by Kruskal Wallis.

Figure 5. NK cell cytotoxicity in asthma patients with and without FAO (A+FAO, A-FAO) and healthy individuals (H). Isolated peripheral NK cells were incubated with target K562 cells for 4 hours, and lactate dehydrogenase (LDH) levels used 
to determine cytotoxicity levels. There were no statistically significant differences in NK cell cytotoxicity levels between the three participant groups. Data analysed by ANOVA.

1

2

3

4

5

6

10

11

12

13

14

15

16

17

18

19

20

21

22

23

24

25

26

27

28

29

30

31

32

33

34

35

36

37

38

39

40

41

42

43

44

45

46

47

48

49

50

51

52

53

54

55

56

57

58

59

60 

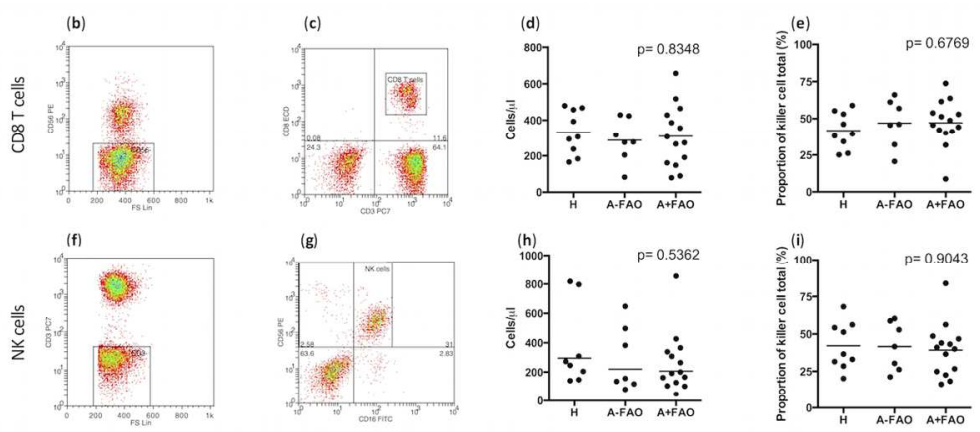

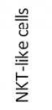
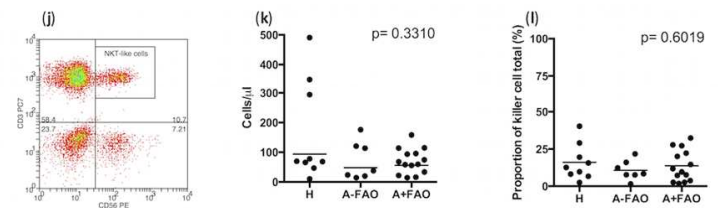

Figure 1. Peripheral killer cell numbers in asthma patients with and without $F A O(A+F A O, A-F A O)$ and healthy individuals $(\mathrm{H})$. Whole blood was mixed with flow-count fluorosphere beads, incubated with fluorescently-conjugated antibodies and analysed by flow cytometry. Lymphocytes (L) and flow-count fluorosphere beads (B) were identified based on forward and side scatter (a). CD8 T cells (CD8+CD3+CD56, b-e), NK cells (CD56+CD3-, f-i) and NKT-like cells (CD56+CD3+, j-l) were identified from the lymphocyte population (representative plots shown) and displayed as cells per $\mu l(d, h, k)$ and as a proportion of the total killer cell number $(e, i, l)$. There were no statistically significant differences in killer cell number, or the proportion of the killer cell total this value represented, between the three participant groups for any of the three killer cell types. ( $h$ ) and $(k)$ log transformed. All data analysed by ANOVA.

\section{$577 \times 288 \mathrm{~mm}(72 \times 72 \mathrm{DPI})$}




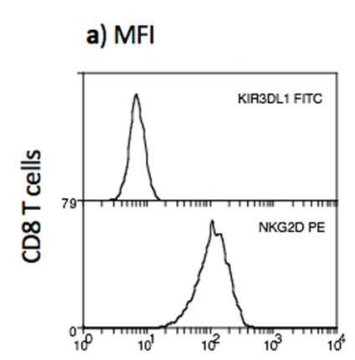

(b) NKG2D
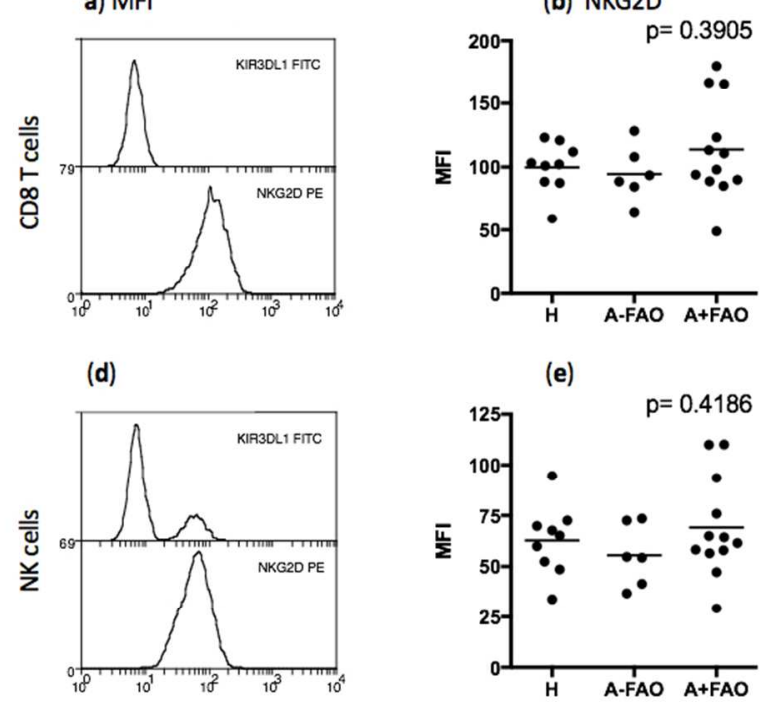

(g)

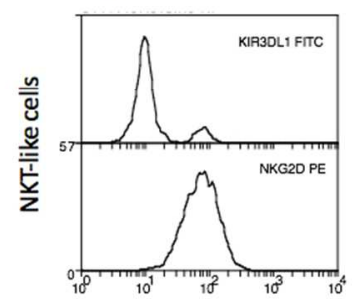

(e)
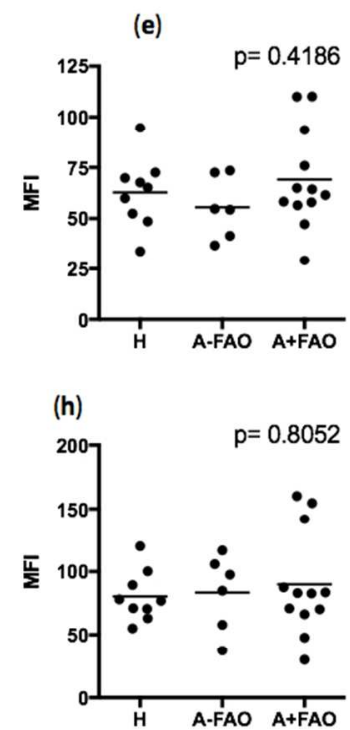

(c) KIR3DL1

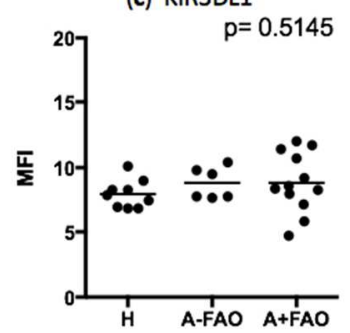

(f)

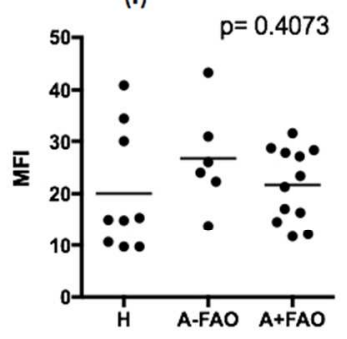

(i)

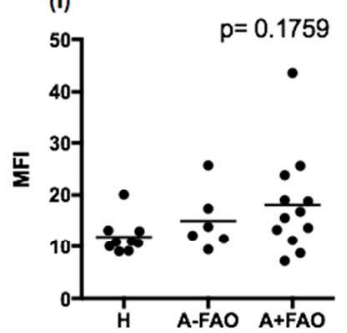

Figure 2. NKG2D and KIR3DL1 receptor expression in killer cells from asthma patients with and without FAO $(A+F A O, A-F A O)$ and healthy individuals $(H)$. Separated PBMC were stained with fluorescently-conjugated antibodies and analysed by flow cytometry. CD8 T cells (a-c), NK cells (d-f) and NKT-like cells ( $g-i)$ were identified (representative plots shown), and the NKG2D and KIR3DL1 expression of each was displayed as mean fluorescence intensity (MFI). There were no statistically significant differences in NKG2D or KIR3DL1 expression between the three participant groups for any of the killer cell types. (i) Log transformed. All data analysed by ANOVA.

$332 \times 297 \mathrm{~mm}(72 \times 72$ DPI $)$ 

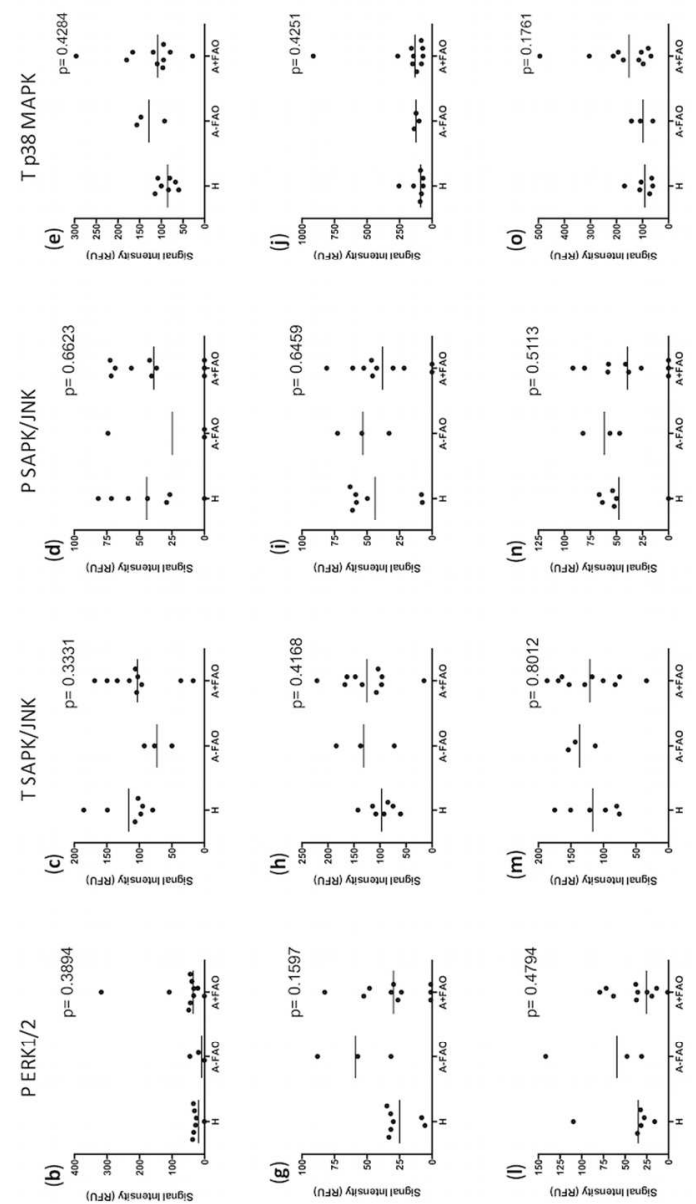

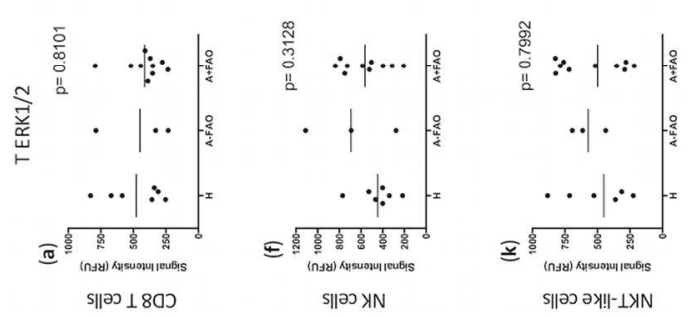

Figure 3. MAPK signalling molecule expression in killer cells from asthma patients with and without FAO (A+FAO, A-FAO) and healthy individuals $(H)$. Levels of total $(T)$ and phosphorylated $(P)$ ERK1/2, SAPK/JNK and p38 MAPK were measured in isolated CD8 T cells $(a-e)$, NK cells $(f-j)$ and NKT-like cells $(k-0)$, by reverse phase protein lysate microarray (RPMA). Background values were subtracted from the signal intensities, before normalisation to actin expression. There were no statistically significant differences in the expression of any of the signalling molecules between the three participant groups for any of the three killer cell types. Values are expressed in relative fluorescent units (RFU). (b), (e), (k), (I) and (o) Log transformed. All data analysed by ANOVA, except (j)- analysed by Kruskal Wallis.

$253 \times 576 \mathrm{~mm}(72 \times 72$ DPI $)$ 

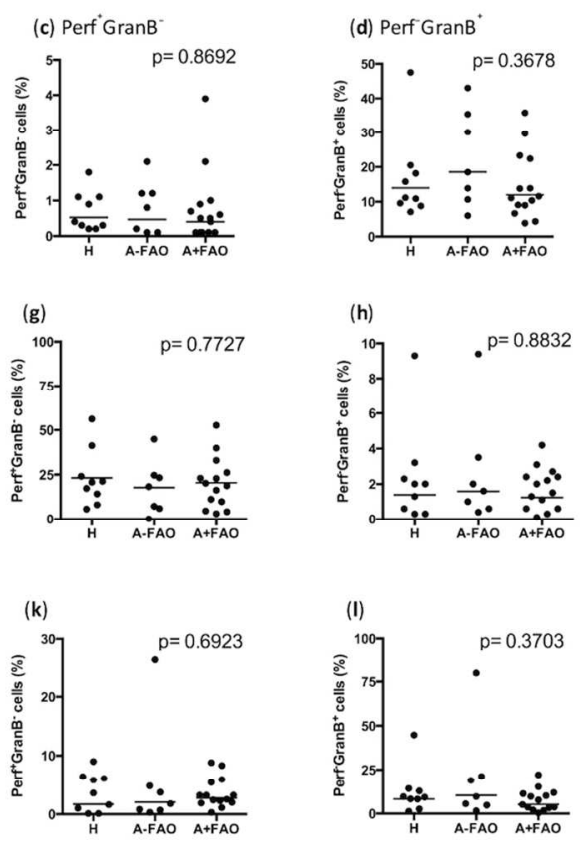

Figure 4. Perforin and granzyme $B$ expression in killer cells from asthma patients with and without FAO $(A+F A O, A-F A O)$ and healthy individuals $(\mathrm{H})$. PBMC were isolated and stained with fluorescently-conjugated antibodies before analysis by flow cytometry. CD8 T cells (a-d), NK cells (e-h) and NKT-like cells (i-I) were identified and the perforin and/or granzyme $B$ expression of each was quantified. There were no statistically significant differences in the expression of either of the two cytotoxic mediators between the three participant groups for any of the killer cell types. (c), (d), (h), (k) and (I) Log transformed. All data analysed by ANOVA, except (j)- analysed by Kruskal Wallis.

$468 \times 327 \mathrm{~mm}(72 \times 72$ DPI $)$ 


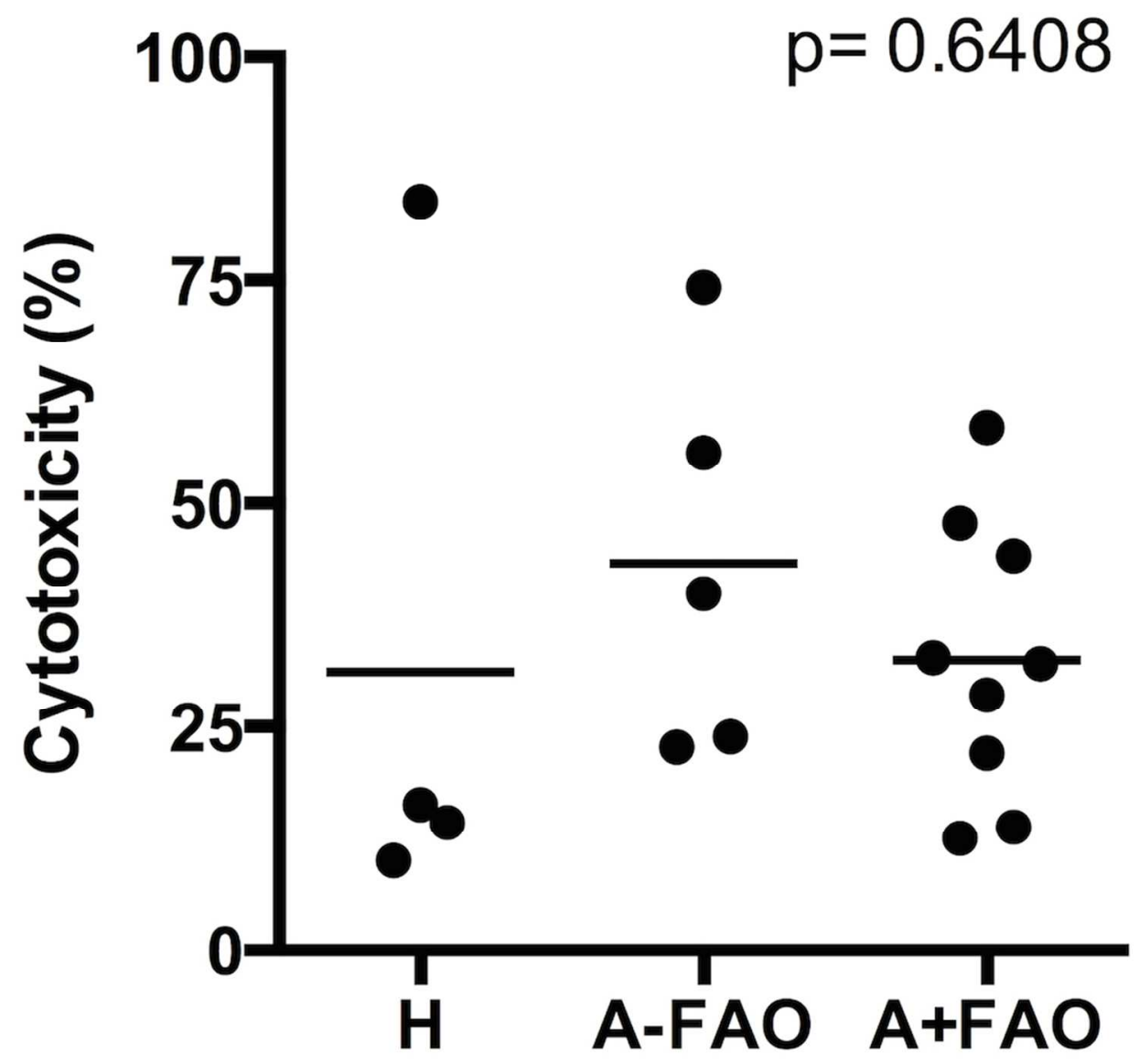

Figure 5. NK cell cytotoxicity in asthma patients with and without FAO (A+FAO, A-FAO) and healthy individuals $(H)$. Isolated peripheral NK cells were incubated with target K562 cells for 4 hours, and lactate dehydrogenase (LDH) levels used to determine cytotoxicity levels. There were no statistically significant differences in NK cell cytotoxicity levels between the three participant groups. Data analysed by ANOVA.

$360 \times 333 \mathrm{~mm}(72 \times 72 \mathrm{DPI})$ 
Table 1. Subject demographic and spirometric data

\begin{tabular}{|c|c|c|c|c|c|c|c|c|c|}
\hline & \multicolumn{3}{|c|}{$\begin{array}{l}\text { (a) Full cohort- cell numbers, receptor } \\
\text { expression and cytotoxic mediator expression }\end{array}$} & \multicolumn{3}{|c|}{ (b) MAPK signalling pathways } & \multicolumn{3}{|c|}{ (c) NK cell cytotoxicity } \\
\hline & $\mathbf{H}$ & A-FAO & A+FAO & $\mathbf{H}$ & A-FAO & A+FAO & $\mathbf{H}$ & A-FAO & A+FAO \\
\hline Subjects & 9 & 7 & 14 & 7 & 3 & 10 & 4 & 5 & 9 \\
\hline Age (years) & $57(52-62)$ & $66(60-74)$ & $67(58-71)$ & $55(49-57)$ & $64(60-74)$ & $68(58-73)$ & $56(51-59)$ & $73(58-75)$ & $65(56-68)$ \\
\hline Gender $(\mathrm{M} / \mathrm{F})$ & $6 / 3$ & $1 / 6$ & $9 / 5$ & $5 / 2$ & $0 / 3$ & $8 / 2$ & $2 / 2$ & $0 / 5$ & $7 / 2$ \\
\hline Post-bronch $\mathrm{FEV}_{1}(\mathrm{~L})$ & $\begin{array}{l}3.14(2.92- \\
3.96)\end{array}$ & $\begin{array}{l}2.05(1.62- \\
2.78)\end{array}$ & $\begin{array}{c}1.73(1.47- \\
2.10)\end{array}$ & $\begin{array}{c}3.14(3.02- \\
4.14)\end{array}$ & $\begin{array}{l}2.02(1.62- \\
2.18)\end{array}$ & $\begin{array}{c}1.65(1.55- \\
1.80)\end{array}$ & $\begin{array}{l}2.98(2.81- \\
3.89)\end{array}$ & $\begin{array}{l}2.05(1.58- \\
2.52)\end{array}$ & $\begin{array}{c}1.69(1.43- \\
1.80)\end{array}$ \\
\hline $\begin{array}{l}\text { Post-bronch FEV } 1 \\
\text { (\%pred) }\end{array}$ & $\begin{array}{c}112(101- \\
117)\end{array}$ & $103(97-110)$ & $64(55-76)$ & $109(95-113)$ & $98(97-116)$ & $64(55-79)$ & $114(108-121)$ & $103(95-113)$ & $59(46-70)$ \\
\hline Post-bronch FVC (L) & $\begin{array}{c}4.05(3.71- \\
4.78)\end{array}$ & $\begin{array}{l}2.73(2.22- \\
3.75)\end{array}$ & $\begin{array}{c}2.89(2.39- \\
4.02)\end{array}$ & $\begin{array}{c}4.05(3.68- \\
4.98)\end{array}$ & $\begin{array}{l}2.73(2.22- \\
2.89)\end{array}$ & $\begin{array}{c}3.07(2.50- \\
4.02)\end{array}$ & $\begin{array}{c}3.82(3.46- \\
4.79)\end{array}$ & $\begin{array}{l}2.40(2.07- \\
3.24)\end{array}$ & $\begin{array}{c}3.08(2.36- \\
4.17)\end{array}$ \\
\hline Post-bronch FVC (\%pred) & $\begin{array}{c}110(102- \\
121)\end{array}$ & $116(100-121)$ & $88(76-109)$ & $106(100-118)$ & $116(110-121)$ & $84(76-105)$ & $115(108-132)$ & $110(97-122)$ & $90(76-101)$ \\
\hline Post-bronch $\mathrm{FEV}_{1} / \mathrm{FVC}$ & $\begin{array}{c}0.81(0.78- \\
0.83)\end{array}$ & $\begin{array}{c}0.76(0.73- \\
0.80)\end{array}$ & $\begin{array}{c}0.59(0.50- \\
0.67)\end{array}$ & $\begin{array}{c}0.82(0.79- \\
0.83)\end{array}$ & $\begin{array}{c}0.73(0.70- \\
0.80)\end{array}$ & $\begin{array}{c}0.59(0.51- \\
0.67)\end{array}$ & $\begin{array}{c}0.78(0.76- \\
0.82)\end{array}$ & $\begin{array}{c}0.80(0.75- \\
0.83)\end{array}$ & $\begin{array}{c}0.55(0.46- \\
0.59)\end{array}$ \\
\hline $\begin{array}{l}\text { Airflow obstruction } \\
\text { severity (mild/moderate/ } \\
\text { severe/ very severe)* }\end{array}$ & $\mathrm{n} / \mathrm{a}$ & $\mathrm{n} / \mathrm{a}$ & $3 / 8 / 2 / 1$ & $\mathrm{n} / \mathrm{a}$ & $\mathrm{n} / \mathrm{a}$ & $2 / 6 / 2 / 0$ & $\mathrm{n} / \mathrm{a}$ & $\mathrm{n} / \mathrm{a}$ & $1 / 5 / 2 / 1$ \\
\hline $\begin{array}{l}\text { Age of asthma onset } \\
\text { (years) }\end{array}$ & $\mathrm{n} / \mathrm{a}$ & $46(39-54)$ & $8(6-51)$ & $\mathrm{n} / \mathrm{a}$ & $50(42-53)$ & $8(6-42)$ & $\mathrm{n} / \mathrm{a}$ & $50(41-55)$ & $10(6-56)$ \\
\hline Disease duration (years) & $\mathrm{n} / \mathrm{a}$ & $22(15-30)$ & $45(18-59)$ & $\mathrm{n} / \mathrm{a}$ & $24(6-30)$ & $53(20-63)$ & $\mathrm{n} / \mathrm{a}$ & $20(12-27)$ & $47(11-57)$ \\
\hline
\end{tabular}




\begin{tabular}{|c|c|c|c|c|c|c|c|c|c|}
\hline $\begin{array}{l}\text { Asthma severity (GINA } \\
\text { treatment step } \\
1 / 2 / 3 / 4 / 5)^{* *}\end{array}$ & $\mathrm{n} / \mathrm{a}$ & $0 / 3 / 3 / 1 / 0$ & $0 / 1 / 7 / 6 / 0$ & $\mathrm{n} / \mathrm{a}$ & $0 / 1 / 1 / 1 / 0$ & $0 / 1 / 4 / 4 / 0$ & $\mathrm{n} / \mathrm{a}$ & $0 / 2 / 2 / 1 / 0$ & $0 / 1 / 3 / 5 / 0$ \\
\hline $\begin{array}{l}\text { Inhaled corticosteroids } \\
\text { (ICS) }(\mathrm{Y} / \mathrm{N})\end{array}$ & $\mathrm{n} / \mathrm{a}$ & $7 / 0$ & $14 / 0$ & $\mathrm{n} / \mathrm{a}$ & $3 / 0$ & $10 / 0$ & $\mathrm{n} / \mathrm{a}$ & $5 / 0$ & $9 / 0$ \\
\hline $\begin{array}{l}\text { Long-acting beta agonists } \\
\text { (LABAs) }(\mathrm{Y} / \mathrm{N})\end{array}$ & $\mathrm{n} / \mathrm{a}$ & $2 / 5$ & $9 / 5$ & $\mathrm{n} / \mathrm{a}$ & $0 / 3$ & $6 / 4$ & $\mathrm{n} / \mathrm{a}$ & $2 / 3$ & $7 / 2$ \\
\hline $\begin{array}{l}\text { Short-acting beta agonists } \\
(\mathrm{SABAs})(\mathrm{Y} / \mathrm{N})\end{array}$ & $\mathrm{n} / \mathrm{a}$ & $7 / 0$ & $12 / 2$ & $\mathrm{n} / \mathrm{a}$ & $3 / 0$ & $10 / 0$ & $\mathrm{n} / \mathrm{a}$ & $5 / 0$ & $7 / 2$ \\
\hline $\begin{array}{l}\text { Leukotriene modifiers } \\
(\mathrm{Y} / \mathrm{N})\end{array}$ & $\mathrm{n} / \mathrm{a}$ & $0 / 7$ & $1 / 13$ & $\mathrm{n} / \mathrm{a}$ & $0 / 3$ & $1 / 2$ & $\mathrm{n} / \mathrm{a}$ & $0 / 5$ & $1 / 8$ \\
\hline Atopic $(\mathrm{Y} / \mathrm{N})$ & $2 / 7$ & $6 / 1$ & $9 / 5$ & $1 / 6$ & $3 / 0$ & $7 / 3$ & $0 / 4$ & $5 / 0$ & $6 / 3$ \\
\hline $\begin{array}{l}\text { Smoking status } \\
\text { (current/ex/never) }\end{array}$ & $0 / 1 / 8$ & $0 / 4 / 3$ & $0 / 2 / 12$ & $0 / 1 / 6$ & $0 / 2 / 1$ & $0 / 1 / 9$ & $0 / 0 / 4$ & $0 / 2 / 3$ & $0 / 0 / 9$ \\
\hline Pack years & $0(0-0)$ & $1(0-2)$ & $0(0-0)$ & $0(0-1.5)$ & $1.5(0-2)$ & $0(0-0)$ & $0(0-0)$ & $0(0-1.5)$ & $0(0-0)$ \\
\hline CD8 T cell purity (\%) & & & & $\begin{array}{c}93.6(90.9- \\
95.0)\end{array}$ & 92.9 (83.9-95) & $\begin{array}{c}91.9(88.4- \\
94.2)\end{array}$ & & & \\
\hline NK cell purity (\%) & & & & $\begin{array}{c}97.5(95.7- \\
98.3)\end{array}$ & $\begin{array}{c}97.3(96.5- \\
98.1)\end{array}$ & 97 (93.6-98.8) & $\begin{array}{c}97.9(96.2- \\
98.4)\end{array}$ & $\begin{array}{c}97.6(96.3- \\
98.1)\end{array}$ & $\begin{array}{c}97.6(93.3- \\
98.3)\end{array}$ \\
\hline NKT-like cell purity (\%) & & & & $\begin{array}{l}82.5(71.2- \\
90.0)\end{array}$ & $\begin{array}{c}75.7(55.4- \\
92.4)\end{array}$ & $\begin{array}{c}73.9(58.1- \\
92.6)\end{array}$ & & & \\
\hline
\end{tabular}

Results expressed as the median with the interquartile range in brackets. A+/-FAO, asthma patients with/without fixed airflow obstruction; $\mathrm{H}$, healthy individuals.

*Based on post-bronchodilator $\mathrm{FEV}_{1}$ (\%pred): > $80 \%$ mild, 50-79\% moderate, $30-49 \%$ severe, and $<30 \%$ very severe. **Based on drug treatment [51]. 
Table 2. Antibodies used in flow cytometry and reverse phase protein lysate microarray (RPMA)

\begin{tabular}{|c|c|c|c|c|c|}
\hline Target & Conjugate & Clone & Company & $\begin{array}{c}\text { Catalogue } \\
\text { number }\end{array}$ & Lot number \\
\hline \multicolumn{6}{|c|}{ Flow cytometry } \\
\hline CD3 & ECD & UCHT1 & Beckman Coulter & A07748 & 30 \\
\hline CD3 & PC7 & UCHT1 & Beckman Coulter & 737657 & 7973014 \\
\hline CD8 & ECD & SFCI21Thy2D3 & Beckman Coulter & 737659 & 7974018 \\
\hline CD8 & PC5 & HIT8a & BD Pharmingen & 555636 & 98195 \\
\hline CD56 & PE & N901 (NHK-1) & Beckman Coulter & A07788 & 13 \\
\hline CD56 & PC5 & N901 (NHK-1) & Beckman Coulter & A07789 & 15 \\
\hline Granzyme B & FITC & GB11 & BD Pharmingen & 560211 & 37817 \\
\hline KIR3DL1 & FITC & DX9 & BioLegend & 312706 & B110125 \\
\hline NKG2D & PE & ON72 & Beckman Coulter & A08934 & 13 \\
\hline Perforin & $\mathrm{PE}$ & $\delta \mathrm{G} 9$ & BD Pharmingen & 556437 & 46510 \\
\hline \multicolumn{6}{|c|}{ Reverse phase protein lysate microarray (RPMA) } \\
\hline T ERK1/2 & - & - & Cell Signalling & 4695 & 13 \\
\hline T p38MAPK & - & - & Cell Signalling & 9212 & 13 \\
\hline T SAPK/JNK & - & - & Cell Signalling & 9258 & 9 \\
\hline P ERK1/2 & - & - & Cell Signalling & 9101 & 26 \\
\hline P SAPK/JNK & - & - & Cell Signalling & 4668 & 7 \\
\hline
\end{tabular}

CD, cluster of differentiation; ECD, phycoerythrin-Texas Red; ERK1/2, extracellular signalregulated kinase 1 and 2; FITC, fluorescein isothiocyanate; PC5, phycoerythrin cyanin 5; KIRx, killer cell immunoglobulin-like receptor $\mathrm{x}$; KLRx, killer cell lectin-like receptor $\mathrm{x}$; $\mathrm{P}$, phosphorylated; p38 MAPK, p38 mitogen-activated protein kinase; PC7, phycoerythrin cyanin 7; PE, phycoerythrin. SAPK/JNK, stress-activated protein kinase and c-Jun N-terminal kinase; T, total. 